\title{
PENGALAMAN PERAWAT IGD MERAWAT PASIEN DO NOT RESUSCITATE PADA FASE PERAWATAN MENJELANG AJAL
}

\author{
Maria Imaculata Ose ${ }^{1^{*}}$ \\ 1. Fakultas Ilmu Kesehatan Universitas Borneo Tarakan, Kalimantan Utara 77123, Indonesia \\ *E-mail: onijuntak@gmail.com
}

\begin{abstract}
Abstrak
Do Not Resuscitate (DNR) menjadi keputusan yang tidak mudah diambil oleh dokter dan membutuhkan pertimbangan dan rekomendasi dari perawat. Keterbatasan pengalaman, pengetahuan dan informasi DNR, kriteria IGD yang lebih berfokus pada perawatan gawat darurat menyebabkan tidak dapat maksimalnya peran perawat dalam perawatan menjelang ajal. Tujuan penelitian ini adalah mengeksplorasi pengalaman perawat di IGD dalam merawat pasien DNR di ruang IGD. Desain Penelitian dengan metode Kualitatif pendekatan Fenomenologi interpretif, partisipan empat perawat IGD. Data dikumpulkan melalui Indepth interview, menggunakan analisis tematik Braun dan Clark. Hasil Penelitian empat tema yaitu 1. Memahami kegagalan resusitasi merupakan pasien DNR, 2. Melakukan resusitasi sebagai Protap Penanganan awal, 3. Berkolaborasi mengambil keputusan DNR, 4. Menyiapkan kematian pasien dengan baik. Kesimpulannya yaitu pengambilan keputusan DNR (Do Not Resuscitate) membutuhkan pertimbangan dan pemahaman pada kriteria DNR, selain itu perawat harus terlibat dalam kolaborasi dengan tim yang merawat pasien, sehingga keputusan DNR tepat. Perawatan DNR di IGD memberikan resusitasi sebagai tindakan awal dan mempersiapkan kematian pasien dengan baik dengan melibatkan keluarga pasien.
\end{abstract}

Kata kunci: DNR, perawatan menjelang ajal, perawat IGD

\begin{abstract}
Experience of ER Nurse in Treating Do Not Resuscitate Patients in End of Life Care Phase. Do Not Resuscitate (DNR) is a difficult decision for doctors to make. In making the decision, the doctors need to consider nurses' recommendation. Due to limited knowledge, experiences, and information of DNR, plus the criteria of emergency department which are only focused on emergency treatments, the nurses cannot maximize their roles in the end of life care. This study, thus, aimed to explore the nurses' experiences in the emergency rooms especially in taking care of DNR patients. This research employed a qualitative method that was interpretive phenomenology approach involving four nurses who were working in the emergency department. Data was collected through in depth interview, using thematic analysis suggested by Braun \& Clark. The results of the study cover four themes; they are to 1. Understand the failure of resuscitation during the treatment, 2. Perform resuscitation as an early standard operating procedure to treat patients 3. Collaborate in making decision on DNR, 4. Prepare patients for a good death. The conclusion is before deciding to perform DNR (Do Not Resuscitate), doctors need to understand the criteria of DNR and get nurses involved in it. DNR treatment in the emergency rooms is an early standard operating procedure to treat patients at the end of life phase and to prepare them for a good death by also engaging their family members.
\end{abstract}

Keywords: DNR, end of life care, emergency of nursing

\section{Pendahuluan}

Do Not Resuscitate (DNR) merupakan keputusan untuk tidak melanjutkan tindakan CPR setelah 30 menit tidak menunjukan ada Return of spontaneous circulation (ROSC). Pasien- pasien dengan DNR termasuk dalam kategori sebagai pasien menjelang ajal. Salah satu kompetensi perawat IGD menurut Emergency Nursing Association yaitu memecahkan masalah dengan mengunakan prinsip etik dalam pengambilan keputusan dan memiliki tanggung 
jawab dalam memberikan perawatan menjelang ajal (Wolf, 2015).

Saczynski, et al. (2012) menyebutkan fenomena pengambilan keputusan DNR cenderung meningkat setiap tahunnya, di Massachuesetts pada semua pusat kesehatan pasien mendapatkan DNR adalah sebanyak 1051 orang dari total jumlah 4182 pasien antara tahun 2001 hingga 2007. DNR menjadi keputusan yang tidak mudah diambil oleh dokter dan membutuhkan pertimbangan dan rekomendasi dari perawat (Brizzi, 2012).

Kondisi dilema dirasakan oleh perawat yang timbul akibat dari kurangnya pengalaman, pengetahuan dan informasi terkait DNR. Keterbatasan dan tidak adekuatnya informasi DNR memengaruhi keefektifan pemberian perawatan yang bermartabat (Amestiasih, 2015). Masalah yang juga dihadapi perawat yaitu kurang optimal dalam pengambilan keputusan terkait tingginya tingkat stres dan kecemasan maupun faktor lingkungan IGD (Chan, 2011). Lingkungan ramai, tingginya tuntutan dan waktu tunggu yang lama di IGD menjadi hambatan bagi perawat dalam menyediakan perawatan menjelang ajal secara optimal. Hal ini sejalan dengan yang diungkapkan Bailey, Murphy, dan Porock (2011) bahwa perawatan pasien yang menjelang ajal di IGD terlihat tidak maksimal.

Brizzi (2012) menyebutkan bahwa fokus perawatan yang diberikan terhadap pasien-pasien dengan DNR adalah perawatan menjelang ajal. Alligood dan Tomey (2104) mengungkapkan bahwa perawatan menjelang ajal mempersiapkan pasien menghadapi kematian dengan baik, bertujuan pasien merasakan bebas dari nyeri, merasa kenyamanan, merasa dihargai, dihormati dan berada dalam kedamaian dan ketenangan juga merasa dekat dengan orang dirawatnya.

Perawat memiliki tantangan dalam praktik membantu meningkatkan kualitas hidup selama di IGD melalui pengembangan hubungan an- tara perawat dengan pasien, mempertahankan komunikasi dan bertindak sebagai pelindung untuk pasien selama krisis (Bailey, et al., 2011). Doran (2013) menyebutkan bahwa adanya ketegangan dalam kepedulian sosial atau caring pada Perawat yang bekerja di IGD memiliki pengalaman dalam menghadapi banyak situasi etik yang sulit yang sering mengalami ketegangan emosi dibandingkan dengan perawat lainnya.

Berdasar pengamatan peneliti pada Desember 2015 di IGD RSUD dr. Saiful Anwar, Situasi IGD yang crowded dengan banyaknya jumlah kunjungan pasien, Jumlah kunjungan pasien ke IGD RSUD Dr. Saiful Anwar Malang dalam 3 tahun terakhir yaitu dari tahun 2012 sampai dengan tahun 2014 menunjukkan fluktuasi yaitu pada tahun 2012 jumlah pasien sebesar 30.498 pasien, tahun 2013 berjumlah 31.416 pasien dan tahun 2014 berjumlah 29.891 pasien. Kematian di IGD selama tahun 2014 sebanyak 730 pasien. (Laporan Tahunan RSUD dr. Saiful Anwar Malang, 2014).

Hasil dari wawancara dalam studi pendahuluan yang dilakukan peneliti pada salah satu perawat IGD menjelaskan kurang terlibat dalam pengambilan keputusan terkait dengan kurangnya pengetahuan dan pengalaman, dan persepsi pada pasien DNR bukan termasuk pasien prioritas selain itu lingkungan IGD yang dinilai bukan tempat ideal untuk memberikan perawatan Perawatan menjelang ajal. Perawat IGD mengatakan tidak dapat berpusat dalam mendampingi, memberikan dukungan spiritual pada pasien DNR.

Fenomena kehadiran pasien DNR di IGD menjadi bagian dari tanggung jawab dari peran perawat dalam memberikan perawatan menjelang ajal. Persepsi, pengalaman, pengetahuan dan informasi yang tidak adekuat terkait dengan DNR sehingga perawat mengalami konflik dalam merawat pasien menjelang ajal. Tujuan penelitian ini adalah mengeksplorasi pengalaman perawat di IGD dalam merawat pasien DNR di IGD. 


\section{Metode}

Penelitian ini merupakan penelitian kualitatif dengan pendekatan fenomenologi interpretif. Penelitian ini dilakukan di ruang IGD RSUD dr. Saiful Anwar. Empat orang partisipan dengan teknik purposive sampling berdasarkan kriteria inkulsi. Teknik pengumpulan data dengan Indepth interview. Adapun kriteria partisipan adalah: (1) Perawat yang memiliki pengalaman kerja 8-19 tahun di ruang Critical Care IGD RSUD dr. Saiful Anwar, (2) Perawat yang memiliki pengalaman pengalaman merawat pasien terlantar pada fase Perawatan menjelang ajal (3) Pendidikan partisipan D3 keperawatan-S1 Keperawatan (4) Dalam keadaan sehat secara fisik, (5) Bersedia sebagai partisipan dengan menandatangani surat kesediaan menjadi partisipan. Pada penelitian ini, saturasi data dicapai pada wawancara partisipan ke empat. Analisis data dilakukan dengan menggunakan analisis tematik Braun dan Clarke (2006) terdiri dari 6 tahapan. Penelitian ini telah mendapatkan laik etik di RSUD dr. Saiful Anwar. Keabsahan data untuk mencapai Credibility, Dependability, Confirmability dan Transferability dengan melakukan Triagulasi data, dan inquiry audit.

\section{Hasil}

Hasil penelitian ini ada 4 (empat) tema yaitu: memahami kegagalan resusitasi merupakan pasien DNR, melakukan resusitasi sebagai Protap Penangan awal, berkolaborasi mengambil keputusan DNR, dan menyiapkan kematian pasien dengan baik.

Memahami Kegagalan Resusitasi. Memahami kegagalan resusitasi mengandung makna konstektual mengetahui secara benar dengan mengenal ciri-ciri secara pasti pasien dalam kondisi DNR (Do Not Resuscitate). DNR yaitu tidak melakukan tindakan resusitasi pada pasien. Pada umumnya pasien-pasien DNR pada awal telah dilakukan tindakan resusitasi, namun pada perjalanan penyakit menunjukan indikasi-indikasi tidak adanya perbaikan pada kondisi tanda-tanda vital baik dari Tekanan darah, nadi, suhu, pernafasan, saturasi oksigen maupun status kesadaran.

“... awalnya tentu yang dikatakan DNR itu adalah pasien sudah tidak ada nafas, nafasnya tidak spontan, ada cuman jantungnya aja, kita cek refleks gaps, kita jadikan patokannya, refleks pupil, refleks batuk dan menelan, tapi nadinya masih ada ..." (P1)

Kondisi pasien dengan DNR antara lain pasien dengan kondisi kritis dan pasien dengan penyakit terminal. Perawat menyebutkan pasienpasien yang ditemukan pada dengan kondisi kritis yang sudah tidak menunjukan adanya perbaikan setelah dilakukan resusitasi menunjukan pasien-pasien tersebut dapat diputuskan DNR. Hal ini seperti yang diungkapkan oleh perawat:

“...DNR itu kalau pasiennya mengalami kegagalan multidisfunction atau multiorgan failure, jadi diresusitasi tidak respone... jadi nanti ada beberapa point yang nanti kesimpulannya pasiennya DNR..." (P2)

Selain pada pasien dengan kondisi kritis, pada pasien yang masuk ke ruang gawat darurat dengan kondisi terminal dan penyakitpenyakit, yaitu seperti kanker, yang memiliki riwayat dirawat dengan penyakit yang sama dalam kondisi penyakit yang serius atau penyakit regeneratif.

“... pasien yang DNR itu umumnya sebelum di DNR kan pasiennya P1 karena ada yang sudah dirawat kemudian DNR dan ada yang aslinya dari sana sudah DNR... artinya begini... sudah dirawat pasiennnya sudah sakit kronis pasien sepsis sudah lama, sudah berbulan-bulan dirumah sakit swasta atau rumah sakt luarlah dirujuk ke kita dengan kondisi jelek... sehingga dirawat tapi gagal resusitasi dan di lebel DNR..." (P2) 
“... DNR, do not resuscitate artinya pasien itu sudah... contoh pasien bila datang kesini pasien sudah kronis kayak kanker dengan stadium berapa ... itu istilahnya seandainya kita resusitasi dia akan memperpanjang... istilah kasihan...” (P3)

Berdasarkan pernyataan di atas dapat dijelaskan perawat memahami kegagalan resusitasi merupakan pasien DNR di IGD dengan kondisi pasien kritis dan penyakit terminal yang mana pada pasien tersebut sudah tidak menunjukkan adanya perbaikan setelah dilakukan resusitasi.

\section{Melakukan Resusitasi sebagai Protap} Penanganan Awal. Pada saat pasien datang ke IGD maka perawat akan melakukan triage pada pasien tersebut. Pasien-pasien dengan penyakit kronik dan penyakit terminal yang memiliki penurunan kesehatan sangat signifikan sehingga perawat melakukan pengkajian dan pemeriksaan pada tahap awal. Penurunan kesehatan ditandai dengan adanya manifestasi kegagalan multiorgan ditandai dengan penurunan dari airway, breathing, circulation dan status kesadaran. Pasien yang telah dilakukan penilaian triage maka segera dilakukan tindakan resusitasi berdasarkan prioritas sesuai dengan protap yang diberlaku di IGD.

“... yah tetap kita tangani jadi P1 dulu..." (P1)

“... biasanya pasien kalau kesini dia... biasanya kalau di tanya di anamnese dengan penyakitnya apa ini,... memang perlu resusitasi... resusitasi awal karena... kita beranggapan kan kita tidak mengerti... pasti pasien diresusitasi dulu..." (P3)

Pemeriksaan penunjang menjadi suatu bagian yang dilakukan yang terpenting dilakukan. Hasil dan pemeriksaan penunjang dapat menjelaskan penyebab dari kondisi pasien, dan menjadi pertimbangan dalam menentukan intervensi selanjutnya pada pasien dan tidak langsung ditentukan sebagai pasien DNR.
“... sebelum kita ngomong DNR harus ada pemeriksaan dari dokternya... bukan hanya dari perawatnya. DNR tidak segampang itu kita bilang DNR... harus ada banyak rantai pemeriksaannya..." (P1)

“... kalau misalnya sudah gak ada nafas anggap saja sudah... yah mungkin orang awam yah kalau sudah tidak ada nafas anggap aja meninggal sudah... orang kesehatan kan gak gitu harus pemeriksaan penunjang yang lain." (P3)

\section{Berkolaborasi Mengambil Keputusan DNR.}

Berkolaborasi merupakan tindakan dan interaksi yang dibutuhkan oleh tim secara komprehensif terkait dalam mengambil dan menentukan keputusan DNR pada pasien tersebut. Keputusan dilakukan secara bersama dalam memberikan label DNR yang nantinya akan digelangkan pada pasien.

“... DNR itu tidak bisa diputuskan oleh 1 orang, misalnya dari bedah, anastesi, dan salah satu dari IPD, atau EM nya atau syaraf, jadi 3 orang dari secound opini (opini alternatif) baru dapat disimpulkan pasien itu DNR..." (P1)

“... perawatnya terlibat pada saat pengkajian DNR, controlling akhir pengisian form $D N R . . . "(\mathrm{P} 2)$

DNR diputuskan ketika pasien menunjukan tidak adanya perbaikan setelah dilakukan resusitasi yang ditunjukan dari status hemostatis dan hemodinamik pasien yang dapat diukur dari tanda-tanda vital, nadi, tekanan darah, suhu, maupun saturasi pasien atau dari pantuan lain. Riwayat penyakit kronis, penyakit terminal juga menjadi bagian dari pertimbangan dalam pengambilan keputusan.

“... nanti kalau sudah berhasil mungkin dokter atau siapanya itu... menanyakan anamnesenya penyakit apa ini... kalau misalnya penyakit mohon maaf ini misalnya penyakit B 24 atau pasien yang kanker 
stadium lanjut itu... ow ini pertimbangannya banyak, seandainya arrest lagi... kalau di kita ada namanya form... form DNR itu sama ada stikernya, biasanya kalau sudah ada stikernya atau ada formnya..."

Rumah Sakit Dr. Saiful Anwar memiliki standar operasional prosedur dalam memutuskan DNR pada pasien. Standar Operasional Prosedur mencakup beberapa point yaitu sebelum diputuskan adanya penjelasan secara komprehensif pada keluarga.

Keluarga berperan secara aktif dalam pengambilan keputusan DNR. Penjelasan pada keluarga mencakup bagaimana prognosis, kondisi, maupun harapan hidup dari pasien. Keluarga yang menyetujui DNR dalam sebuah inform consent maka pasien tidak lagi dilakukan resusitasi secara aktif, tindakan RJP maupun tindakan Invasif dan memberikan kematian yang baik bagi pasien.

“... dikasih informasi ke keluarga seandainya sewaktu-waktu dia henti jantung, dia akan menurun kita... silakan keluarga... kita tidak bisa memberikan lama istilahnya henti jantung kita pijat jantung atau apa karena mungkin pasien ada banyak ini pertimbanganya..." (P3)

“... kita sudah tidak akan melakukan tindakan apapun dengan persetujuan keluarga dengan surat pernyataan yang ditanda-tangani dari pihak keluarga dan rumah sakit ataupun dari dokter yang menanganinya... kalau pasien DNR ...." (P4)

Menyiapkan Kematian Pasien dengan Baik. Peran keluarga menjadi pusat dalam perawatan pasien dengan DNR. Keluarga diberikan kesempatan untuk berada disamping pasien untuk memberikan dukungan secara emosi, psikologis maupun spiritual dari pasien. Dengan demikian, hal ini dapat memberikan ketenangan pada pasien DNR yang menjelang ajal. “...sudah DNR... ke keluarga... memberikan secara spiritual... karena secara medis itu atau kesehatan itu yah sudah kita..." (P1)

“... yang kita lakukan adalah pendampingan. Kita memanggil keluarganya untuk bimbingan pasien itu saja... kalau tindakan apa itu kita tidak ada,... jadi kita suruh keluarga untuk mendampingi dan mendoakan... itu membantu itu aja..." (P4)

Sebagian besar keluarga menyampaikan pada perawat bahwa keputusan DNR yang diambil berdasarkan alasan perasaan kasihan dan iba pada pasien. Selain itu, keluarga menginginkan pasien mendapatkan kematian yang baik tanpa dilakukan tindakan yang hanya memperpanjang kondisi kritis pasien.

“... yah rata-rata yang sudah berusaha semaksimal mungkin... bahkan ada yang juga belum dilakukan resusitasi keluarganya sudah menyerah duluan karena apa yah kata kuncinya adalah keluarga... begitu keluarga ngomong pasiennya masih layak dikejar kalau keluarga mengizinkan yah kita kejar... tapi gak yah sudah gak usah dikejar... yah sudah terkait dengan apa namanya hak kepemilikan... milik keluarga..." (P2)

\section{Pembahasan}

DNR merupakan suatu tindakan spesifik untuk tidak memberikan resusitasi jantung paru pada pasien, namun tetap melakukan perawatan rutin (Brizzi, 2012). Keputusan DNR diambil ketika tindakan CPR selama 30 menit tidak menunjukan ada nadi, pernafasan dan respon pasien. Penerapan DNR di IGD RSUD Saiful Anwar yaitu setelah upaya komprehensif mencegah nafas dan henti jantung tidak menunjukkan adanya perbaikan.

Kriteria pasien DNR menurut Brizzi (2012) yaitu pasien usia 75 tahun dengan penurunan 
fungsi organ tubuh, telah mengalami stroke sebelumnya dan perdarahan pada intraventicular dikaitkan dengan ketidakoptimalan hasil yang dicapai apabila dilakukan CPR. Park (2000) menyebutkan DNR suatu tindakan penghentian upaya memperpanjang umur klien. Saczynski (2010) menentukan kriteria DNR yaitu pasien berusia 85 tahun mengalami penuruanan fungsi tubuh, dan mengalami ketergantungan untuk melanjutkan hidupnya, memiliki riwayat komorbiditas seperti diabetes mellitus (DM) hipertensi, dan gagal jantung.

Pemahaman, dan pengetahuan yang baik terkait DNR mendukung perawat dalam mengambilan keputusan tepat dan efektif terkait DNR dan mempersiapkan perawatan menjelang ajal. Hal ini sejalan dengan yang diungkapkan oleh Wolf, (2015) yang menyebutkan kurangnya pemahaman patofisiologi penyakit dalam mengidentifikasi kondisi menjelang ajal menjadi penyebab ketidaksiapan perawat dalam memberikan dukungan sosial dalam perawatan menjelang ajal. Sikap yang positif, keyakinan yang tinggi menjadi indikasi perawat dalam memberikan perawatan menjelang ajal yang berkualitas. Perhatian dan kepedulian maupun manajemen holistik menjadi komponen yang penting dalam perawatan menjelang ajal yang baik.

Lingkungan kerja yang memprioritaskan penanganan dalam menyelamatkan nyawa sehingga tindakan resusitasi merupakan tindakan penangan awal. Pada pemberiaan label DNR di IGD mendapatkan tindakan resusitasi pada tahap awal dan waktu penerapan DNR lebih pendek dibandingkan dengan Penerapan DNR di ICU. Menentukan status DNR diperlukan konsultasi dan kesepakatan antara perawat dengan dokter yang merawat pasien dan atas persetujuan keluarga pasien (Mcmahon, et al., (2009). Kerjasama dan kolaborasi mengarahkan untuk memastikan agar seluruh staf dapat bertanggung jawab dalam perawatan pasien. Semakin baik koordinasi dan komunikasi di antara pihak-pihak yang terlibat dalam proses implementasi, maka terjadi kesalahan-kesalah- an akan sangat kecil untuk tejadi dan begitu pula sebaliknya. Sikap para pelaksana dalam menjalan tugas dan tanggung jawab sebagai pelaksana kebijakan harus dilandasi dengan sikap displin. Di sisi lain, kolaborasi menjadi suatu wadah untuk meningkatkan informasi dan pengetahuan bagi perawat. Hal yang berbeda disampaikan oleh Boyd, et al., (2011) menyebutkan di lapangan kolaborasi antara perawat dengan dokter belum berjalan optimal, dan perawat tidak terlibat dalam komunikasi pengambilan keputusan dan cenderung menyetujui pendelegasian.

Perawat memiliki peran dan tanggung jawab dalam merawat pasien yang menjelang kematian (Calvin, Kite-Powel, \& Hickey, 2007). Perawatan menjelang ajal merupakan salah satu kompetensi yang harus dimiliki perawat IGD yang disebutkan dalam Emergency Nursing Association (Wolf, 2015). Kompetensi tersebut yaitu memiliki pengetahuan dan kemampuan melakukan perawatan pada fase menjelang ajal, bagaimana melakukan persiapan pada pasien maupun memberikan dukungan sosial menjelang kematian (Seiler, et al., 2012). Chan (2005) dan Wolf (2015) menyebutkan bahwa perawatan menjelang ajal dinilai masih kurang diterapkan dalam pelayanan kesehatan terutama di IGD.

Perawatan pasien dalam tahap menjelang ajal, yang membutuhkan penanganan yang bertujuan untuk memberi rasa nyaman, ketenangan, kedekatan support sosial (Beckstrand, et al., 2012, Decker, et al., 2015). Alligood dan Tomey (2014) menyebutkan perawatan menjelang ajal mempersiapkan pasien menghadapi kematian dengan baik, bertujuan pasien merasakan bebas dari nyeri, merasa kenyamanan, merasa dihargai, dihormati dan berada dalam kedamaian dan ketenangan juga merasa dekat dengan orang dirawatnya. Hal yang berbeda disampaikan Mcmahon-Parkes, et al. (2009) menyebutkan petugas di IGD merasakan kurang nyaman dengan adanya kehadiran keluarga saat melakukan tindakan pada pasien, namun memiliki pandangan bahwa pada pasien dengan 
kasus kritis dan gawat, keluarga memiliki hak untuk tetap disisi dan mendampingi pasien. Mcmahon, et al. (2009) menyebutkan petugas di IGD merasakan kurang nyaman dengan adanya kehadiran keluarga saat melakukan tindakan pada pasien, namun memiliki pandangan bahwa pada pasien dengan kasus kritis dan gawat, keluarga memiliki hak untuk tetap disisi dan mendampingi pasien.

Peran keluarga sebagai pendukung pasien selama resusitasi masih jarang diberikan. Steiger dan Balog (2010) menjelaskan kehadiran keluarga dalam proses resusitasi sejak dahulu selalu menjadi kontroversi dan menimbulkan berbagai pendapat baik itu yang bersifat mendukung maupun menolak. Ritme kerja yang cepat dan tekanan yang tinggi dalam proses resusitasi menyebabkan terbatasnya sikap empati, komunikasi dan keterlibatan petugas kesehatan dengan pasien dan keluarga. Meskipun keluarga memiliki kecenderungan emosional, dan keinginan selalu mendampingi pasien namun disisi lain keluarga memiliki respon ansietas dan ketakutan saat pasien dilakukan intervensi. Dengan demikian perawat perlu mengidentifikasi keinginan keluarga dalam memfasilitasi kehadiran yang mampu memberikan perasaan nyaman pada pasien, keluarga maupun tim kesehatan yang merawat.

Hasil penelitian ini menjadi bahan masukan dalam pelayanan perawatan pasien untuk dilakukan ronde keperawatan dan diskusi dengan tenaga kesehatan lain ketika mengambil keputusan DNR dan memberikan pelayanan perawatan menjelang ajal.

\section{Kesimpulan}

Pengambilan keputusan DNR (Do Not Resuscitate) membutuhkan pertimbangan dan pemahaman pada kriteria DNR. Selain itu, perawat harus terlibat dalam kolaborasi dengan tim yang merawat pasien, sehingga keputusan DNR tepat. Perawatan DNR di IGD memberikan resusitasi sebagai tindakan awal dan mempersiapkan kematian pasien dengan baik dengan melibatkan keluarga pasien (YA, YU, TN).

\section{Referensi}

Alligood, M. R. (2014). Nursing theorists and their work. Atlanta, USA: Elsevier Health Sciences.

Amestiasih, T., Ratnawati, R., \& Rini, I.S. (2015). Studi fenomenologi: Pengalaman perawat dalam merawat pasien dengan do not resuscitate (DNR) di Ruang Icu Rsup Dr. Soeradji Tirtonegoro Klaten. Medika Respati, $X, 1-11$. Diperoleh dari http://journal.resp ati.ac.id/index.php/medika/article/view/391

Bailey, C., Murphy, R., \& Porock, D. (2011). Professional tears: Developing emotional intelligence around death and dying in emergency work. Journal of Clinical Nursing, 20 (23-24), 3364-3372. doi: 10.1111/j.1365-2702.2011.03860.x.

Boyd, D., Merkh, K., Rutledge, D.N., \& Randall, V. (2011). Nurses' perceptions and experiences withs end-of-life communication and care. Oncology nursing forum, 38 (3), E229-E239.

Braun, V., \& Clarke, V. (2006). Using thematic analysis in psychologi. Qualitative Research in Psychology, 3, 77-101.

Brizzi, M., Abul-Kasim, K., Jalakas, M., Selariu, E., Pessah-Rasmussen, H., \& Zia, E. (2012). Early do-not-resuscitate orders in intracerebral haemorrhage; frequency and predictive value for death and functional outcome. A retrospective cohort study. Scandinavian journal of trauma, resuscitation and emergency medicine, 20 (1), 1-6.

Calvin, A.O., Kite-Powel, D.M., \& Hickey, J.V. (2007). The neuroscience ICU nurse's perceptions about end of life care. Journal of Neuroscience Nursing, 39 (3), 143-150.

Chan, G.K. (2005). Understanding end-of-life caring practices in the emergency department. Nursing Philosophy, 6 (1), 19-32. 
Chan, G.K. (2011). Trajectories of approaching death in the emergency department: clinician narratives of patient transitions to the end of life. Journal of pain and symptom management, 42 (6), 864-881.

Doran, K.M., Vashi, A.A., Platis, S., Curry, L.A., Rowe, M., \& Gang, M. (2013). Navigating the boundaries of emergency department care: Addressing the medical and social needs of patients who are homeless. Am J Public Health, 103 (Suppl 2), S355-S360. doi: 10.2105/AJPH.2013.301540.

Mcmahon-Parkes, K., Moule, P., Benger, J., \& Albarran, J.W. (2009). The views and preferences of resuscitated and nonresuscitated patients towards familywitnessed resuscitation: A qualitative study. International journal of nursing studies, 46 (2), 220-229.

Saczynski, J.S., Gabbay, E., McManus, D.D., McManus, R., Gore, J.M., Gurwitz, J.H., ... Goldberg, R.J. (2012). Increase in the proportion of patients hospitalized with acute myocardial infarction with do-notresuscitate orders already in place between 2001 and 2007: A nonconcurrent prospective study. Clinical Epidemiology, 4 (1), 267-274. https://doi.org/10.2147/CLEP. S32034.
Seiler, A.J., \& Moss, V.A. (2012). The experiences of nurse practitioners providing health care to the homeless. Journal of the American Academy of Nurse Practitioners, 24 (5), 303-312.

Steiger, N.J., \& Balog, A. (2010). Realizing patient-centered care: Putting patients in the center, not the middle. Frontiers of health services management, 26 (4), 15-26.

Somes, J., \& Donatelli, N.S. (2012). Do Not intubate/do not resuscitate: Treating the severely ill or injured geriatric patient in the emergency department. Journal of Emergency Nursing, 38 (3), 283-286.

Park, Y.R., Kim, J.A., \& Kim, K. (2011). Changes in how ICU nurses perceive the DNR decision and their nursing activity after implementing it. Nursing ethics, 18 (6), 802-813.

Wolf, L.A., Altair, M.D, et al. (2015). Exploring the management of death: Emergency nurses' perceptions of challenges and facilitators in the provision of end-of-life care in the emergency department. Journal of Emergency Nursing, 41 (5), e23-e33.

Laporan Tahunan Rumah Sakit dr. Saiful Anwar Malang Tahun 2010. 